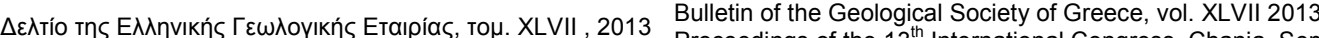

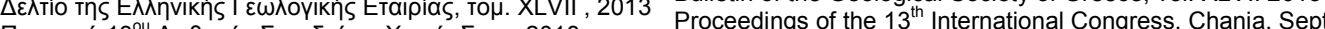

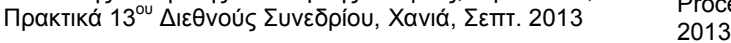

\title{
AN APPLICATION OF GIS ANALYSIS ON STRUCTURAL DATA FROM METAMORPHIC ROCKS IN SANTORINI ISLAND
}

\author{
Marsellos A.E. ${ }^{1,2}$, Foster D.A. ${ }^{2}$, Min K. ${ }^{2}$, Kidd W.S.F. ${ }^{3}$, Garver J. ${ }^{4}$ and \\ Kyriakopoulos K. ${ }^{5}$ \\ ${ }^{1}$ Dept. of Environment and Technology, University of Brighton, BN2 4GJ, U.K. \\ ${ }^{2}$ Dept. of Geological Sciences, University of Florida, Gainesville, Florida 32611, U.S.A. \\ ${ }^{3}$ Dept. of Earth \& Atmos. Sciences, State University of New York, U.S.A. \\ ${ }^{4}$ Dept. of Geology, Union College, Schenectady, NY 12308, New York, U.S.A \\ ${ }^{5}$ Dept. of Geology \& Geoenvironment, National \& Kapodistrian University of Athens, Panepis- \\ timioupolis, GREECE 15784, E.U.
}

\begin{abstract}
The Santorini volcanic island is located in the northern Cretan Sea and is part of the recent subduction-related volcanic arc. The opening of Cretan Sea is the result of extension associated with a series of ductile and brittle detachment faults developed since the Middle Miocene. A detachment between two exhumed metamorphic units is exposed at Athinios, on Santorini Island. Two exhumed metamorphic units are identified that show evidence of similar brittle deformation, but distinctive ductile and ductile-brittle structures. Different thermal histories indicate that a Miocene metamorphic unit is juxtaposed structurally below an Eocene metamorphic unit. In this paper, a prediction map of structural observations in Athinios is generated with statistical and GIS software, and shows a spatial distribution consistent with the exposure of two metamorphic units. K-Mean Cluster analysis using SPSS software on lineation azimuths of the metamorphic rock units shows two populations with center values of $347.2^{\circ} \pm 0.73^{\circ}$ degrees ( $N N W$ to $N$ ) and $003.4^{\circ} \pm 0.83^{\circ}$ degrees ( $N$ to $N N E$ ). NNW-lineation (arc-parallel extension) population belongs to the lower Miocene metamorphic unit and the NNE-lineation represents the Eocene metamorphic unit that was affected by arc-normal extension. A geostatistical map of ordinary Kriging type displays the possible exposed tectonic contacts. This methodology provides a structural prediction map that after field verification facilitates efficient structural and thermochronological sampling.
\end{abstract}

Key words: Geostatistical map, arc-parallel extension, brittle deformation.

\section{Пєрí $\eta \Psi \psi \eta$}

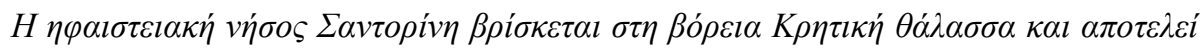

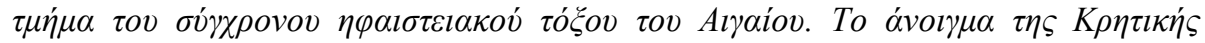

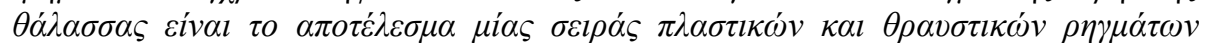

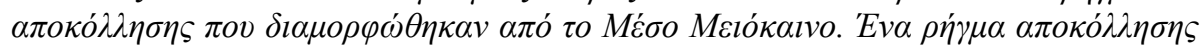

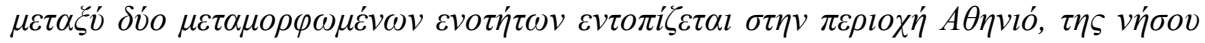

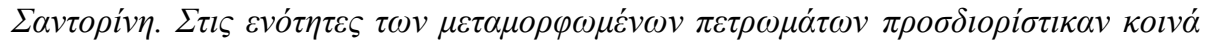

$\underline{\text { XLVII, No } 3-1479}$ 


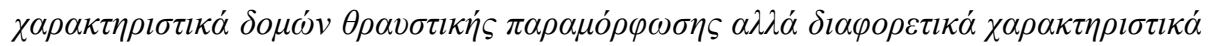

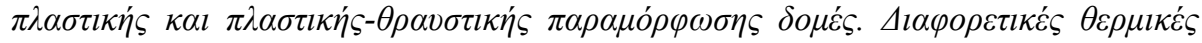

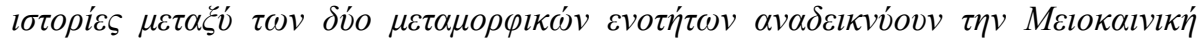

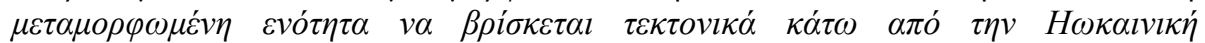

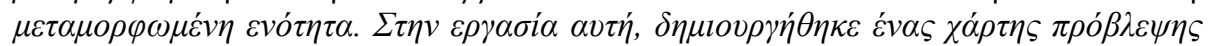

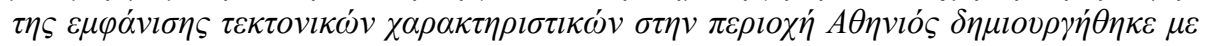

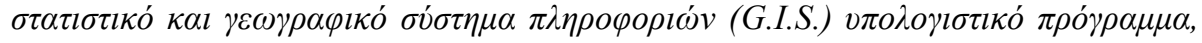

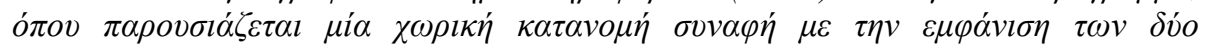

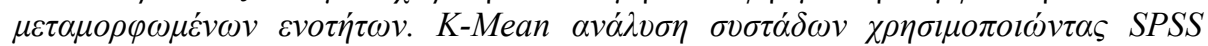

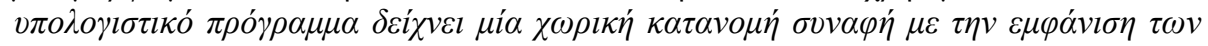

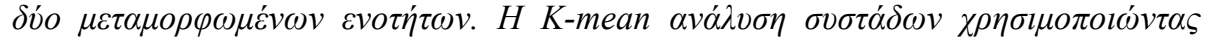

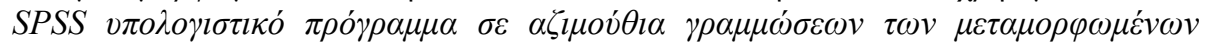

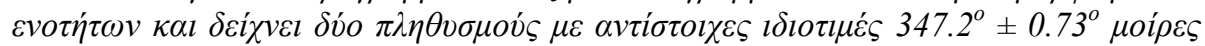

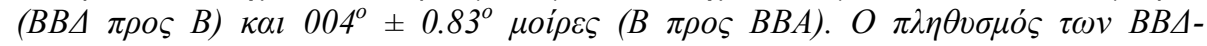

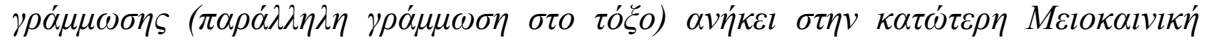

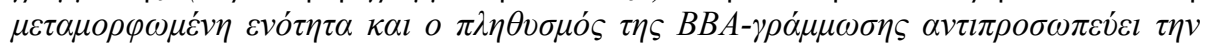

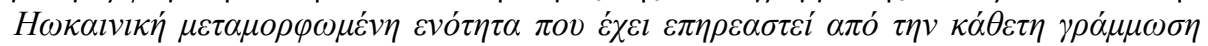

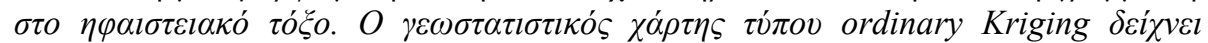

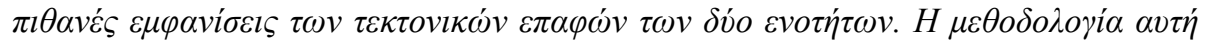

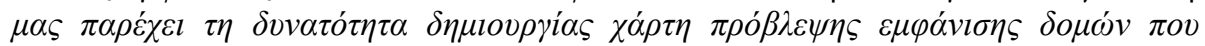

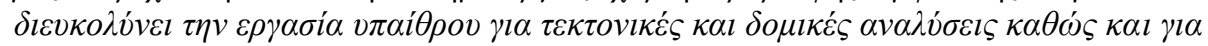

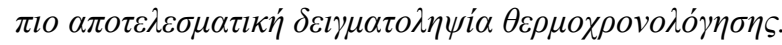

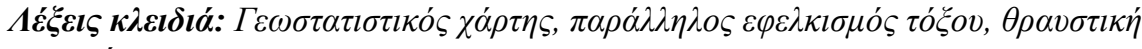
$\pi \alpha \rho \alpha \mu o ́ \rho \varphi \omega \sigma \eta$.

\section{Introduction}

Applied geographical information system (GIS) using structural data integrated with GPS data has become a routine in the field with the use of new and inexpensive technology for digital data collection. The Android platform and the iPhone and iPad have fundamentally changed mobile computing and suggest a new paradigm that will change the nature of field computing and data acquisition. There have been many discussions over the rapid evolution of digital mapping equipment and applications (e.g. Whitmeyer et al., 2010; Pavlis et al., 2012; Doublier \& Hartley, 2012). This raises the need of hands-on geological and geostatistical exercises for students to increase proficiency using modern techonology for efficient high-resolution field data collection. Tablets or cell phones using integrated GPS, gyroscope, and digital compass sensors operating on numerous operational systems have allowed easier field mapping and abundant high-resolution structural data collection (McCaffrey, et al., 2005).

Statistical approach to structural field data applying normal distribution or/and cluster analysis has the potential to provide meaningful classification of metamorphic rocks. Geostatistical methods may reveal distinct structural fabrics thereby defining separate and unique metamorphic units and aid in interpreting tectonic contact. Metamorphic rocks of similar metamorphic conditions but slightly different stretching lineations may require geo- or/and thermo-chronology to provide adequate distinction of those rocks. An efficient method is to integrate all the field data into a GIS and to yield prediction maps to reveal possible tectonic contacts of more than one metamorphic units and suitable sampling locations for structural and thermochronological studies. We present in this paper a GIS technique that can be applied at the field. This methodology has been applied on structural data from metamorphic rocks that exhibit very similar lineations such as the metamorphic rocks of Santorini, and a GIS map has revealed possible locations of tectonic contact that brings two different metamorphic rock units exposed in Santorini.

$\underline{\text { XLVII, No } 3-1480}$ 


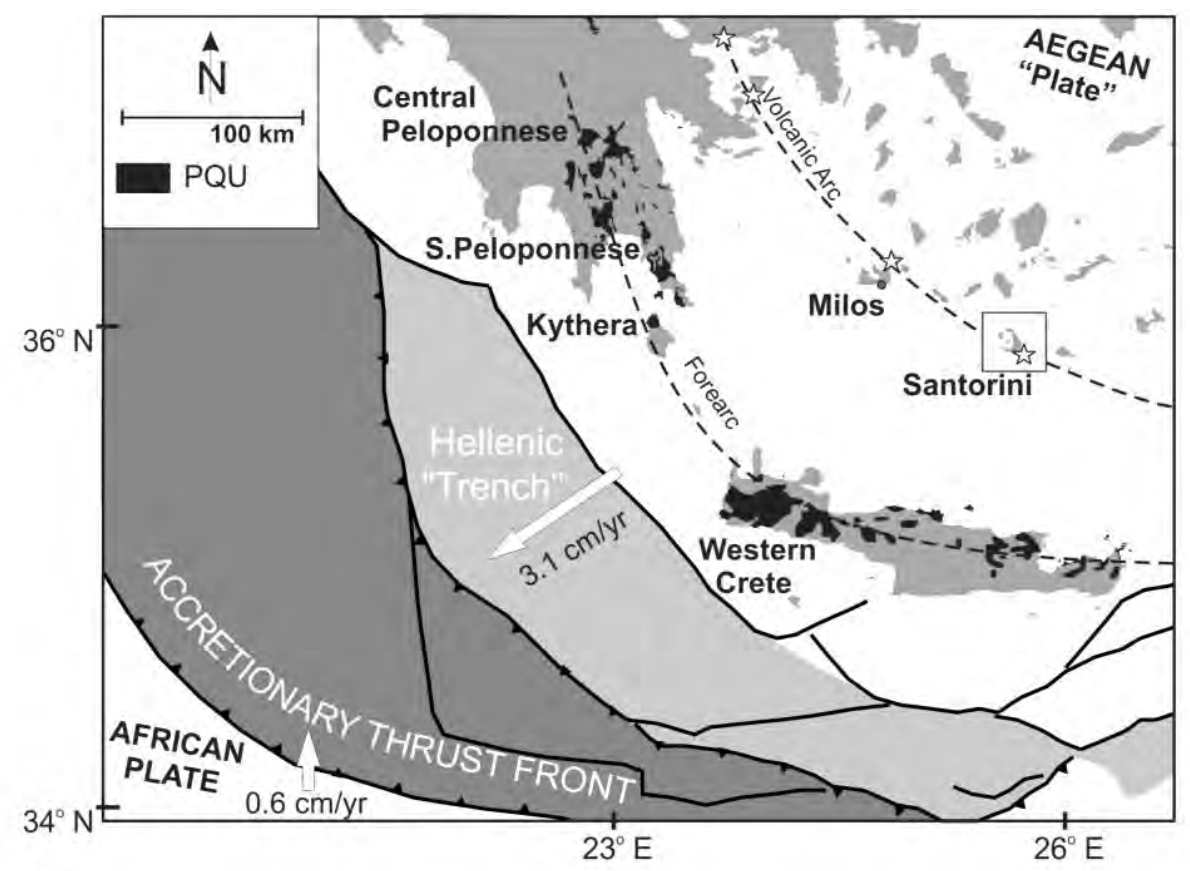

Figure 1 - Tectonic setting of the Hellenic volcanic and forearc which are the result of the interaction between the northward African subducting plate and the overriding Aegean micro-plate. Present GPS Eurasia-Africa relative velocity and average western Hellenic ArcAfrica relative velocity (derived from the average of five stations in western-central Crete, Kythera, and south Peloponnese) after McClusky et al., (2000).

The importance of those rocks is that they show two different post-metamorphic cooling ages and associated exhumation paths in Eocene and Miocene times, respectively (Marsellos et al., 2012). Other Aegean detachment faults such as the Potamos detachment fault in Kythera (Marsellos \& Kidd, 2008) or the southeastern Peloponnese detachment (Marsellos et al., 2010) exhibit metamorphic rocks of similar age, but very different structural-oriented data such as lineations of perpendicular relationship. Very distinctive lineations of approximately $90^{\circ}$ degrees azimuth variation allow easier study of their distribution. On the contrary, lineation population data that comprise one normal distribution such as the Santorini metamorphic rocks may require an advanced statistical approach such as cluster analysis.

The Athinios site was selected because metamorphic rocks are exposed along an appropriate vertical profile allowing detailed analysis of fabric orientations in the exposed Santorini metamorphic rocks. In Athinios port, metamorphic rocks are exposed along an approximately $280 \mathrm{~m}$ vertical profile and a 3,200 $\mathrm{m}$ horizontal section along the road to the port from the mainland.

\section{Tectonic Setting and Geology of Santorini}

One of the most prominent tectonic features of the South Aegean is the Hellenic Arc, which consists of the forearc (Peloponnese, Kythera, Crete, Karpathos and Rhodes) and an inner volcanic arc (Attiki, Methana, Milos, Santorini, Nisiros, Kos). Both arcs are related to subduction of the African plate beneath the European plate and exhumation of high-pressure and low-temperature rocks, during multiple events and via multiple detachment faults (e.g. Fassoulas et al., 1994; Thomson et al., 1998; Lister et al., 2001, Brix et al., 2002, Jolivet et al., 2003, Brun \& Faccena, 2008; Marsellos et al., 2010). 


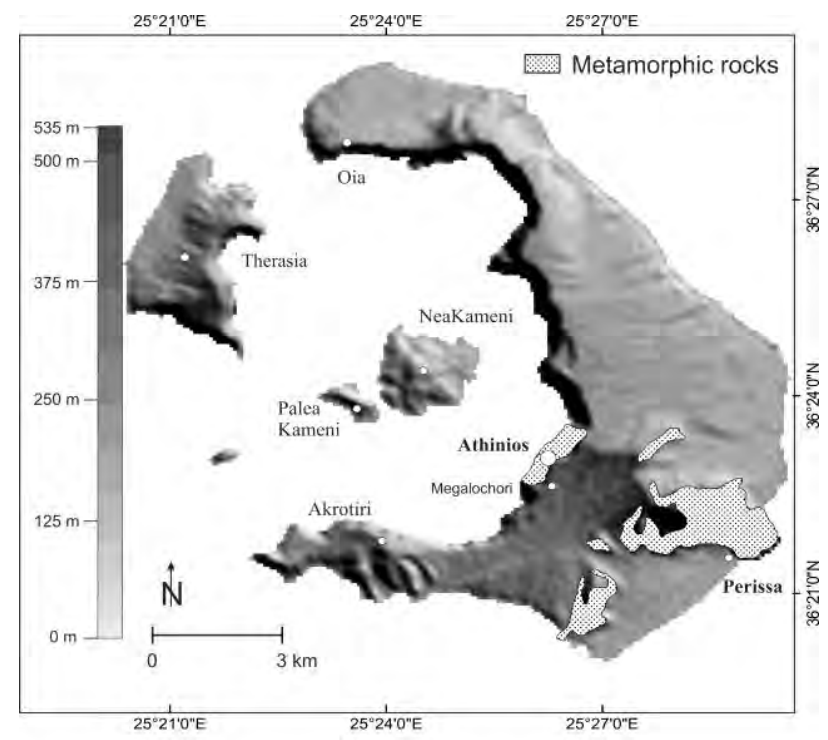

Figure 2 - A hillshade map of Santorini volcanic island. Dot-shaded areas show the exposure of the metamorphic rocks.

The Aegean Sea is an excellent example of episodic extension and exposes a wide range of regional detachment faults (e.g. Fassoulas et al., 1994; Thomson et al., 1999; Brix et al., 2002; Jolivet et al., 2003; Marsellos \& Kidd, 2008; Ring et al., 2010; Skourtsos \& Lekkas, 2010) and localized multi-detachments with more than one extension direction as observed in Kythera and Peloponnese (Marsellos et al., 2010). Correlation between structural data and thermochronological data has been shown to be useful in deconstructing multi-extensional complex tectono-low-thermal histories of HP-rocks associated with arc-normal or/and arc-parallel extensional detachments

Santorini is located at the center of the Recent South Aegean volcanic arc (Figure 1) where a series of active faults accommodate active extension and granitoid intrusion. The metamorphic basement of Santorini consists principally of schists, metapelites, metasandstones and quartzites, metaconglomerates, marbles and metavolcanics (Tataris, A, 1964; Skarpelis \& Liati, 1987;1990). Santorini is dominated mainly by a NNW-SSE extensional stress regime (Mountrakis et al., 1996; Kilias et al., 1996). In Santorini Island, metamorphic rocks occur locally in the southeastern part (Perissa), in the caldera walls (Athinios), and in the outer rim of the island (Figure 2). These rocks have been affected by HP/LT (blueschist facies) metamorphism, and also, they have been intruded by an Itype granite of Late Miocene age ( 9.5 Ma; Skarpelis et al., 1992) which is located at the southernmost part of the Miocene Cycladic granitoid province. Contact metamorphism has been also studied showing skarns and associated ore minerals (Skarpelis and Liati, 1987). Carbonate rocks occur above the metamorphic basement as recrystallized Triassic limestones (Papastamatiou, 1956; Blake et al., 1981). Carbonate and metamorphic rocks are overlain by numerous Pliocene to recent pyroclastics and lavas series. Santorini started to erupt since $200 \mathrm{ka}$ (Druitt and Francaviglia, 1992), with caldera formation at $3.6 \mathrm{Ka}$ during the Minoan eruption (Druitt et al., 1999), and recent activity including the latest eruption being in the 1950's.

\section{Methods}

\subsection{Geographical Information System (GIS) Structural Maps}

To explore the spatial distribution of the structural data of the metamorphic rocks in Athinios, we use GIS software (ArcGIS 10, ESRI). Structural data such as stretching lineation azimuth ( $\mathrm{n}=131$ ) were collected from the metamorphic rocks along a 3,200 $\mathrm{m}$ section from the road of the port of 
Athinios towards Megalochori village (Figure 2, 3). Lineation data were used to develop a contour map using the ordinary krigering geostatistical procedure. A trend analysis was used to examine global trends and directional influences (anisotropy). Due to the topography of this study area data collection shows a persistent slope direction that occurs. This nonrandom component of the surface has been evaluated (Figure 5) and eliminated using a second-order polynomial function assigned by the program. The normality of the data has been verified with a quantile-quantile (QQ) plot (Figure 4). A semivariogram/covariance cloud allowed us to examine the spatial autocorrelation between the measured sample points. A surface map of stretching lineation azimuth data has been produced and shown in Figure 6. This map shows an interesting spatial distribution of two distinctive lineated rocks. Further sampling and dating of those has verified the existence of two metamorphic units (Marsellos et al., 2012).

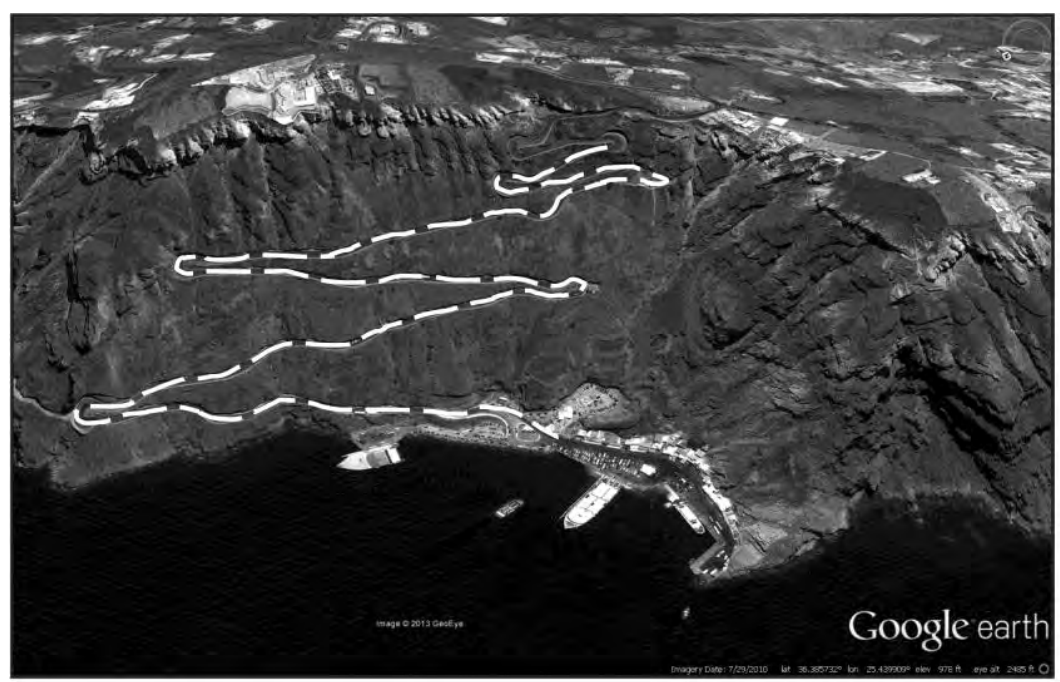

Figure 3 - A Google Earth image (GeoEye scene of 29/07/2010 drapped over a digital elevation model) from the port Athinios in Santorini where a continuous outcrop of approximately 3,200 meters (dashed white line) of exposed metamorphic rocks has been studied.

\subsection{Cluster Analysis}

To statistically verify the existence of the two geological units in the examined location, we apply the statistical method of k-means cluster analysis in the azimuth lineation data. The k-means cluster analysis is a method of cluster analysis that aims to partition the observations ( $\mathrm{n}=131$ observations) into $\mathrm{k}$ clusters in which each observation belongs to the cluster with the nearest mean (Aldenderfer \& Blashfield, 1984; Everitt, 1993). k-means cluster analysis showing two clusters of two different tectono-metamorphic rocks has validated at least two major sampling locations for thermochronological analysis. Those samples, later on, have indicated an Eocene and a Miocene metamorphic unit (Marsellos et al., 2012). Figure 7 and Table 1 shows the azimuth lineation data clusters after the application of the cluster analysis.

Cluster analysis was then implemented in a statistical software package (SPSS). Azimuth lineation data were normalized to avoid artifact clusters in which degree unit yields such as clusters nearby high values or very low values around North direction $\left(000-030^{\circ}\right.$ vs. $\left.330^{\circ}-360^{\circ}\right)$. Two clusters were revealed and plotted on a stereonet with equal angle projection (Figure 7). The range of the lineation values for each population (cluster) has verified the GIS prediction map and shows the possible exposure of the two metamorphic rock units and their associated tectonic contact. This map (Figure 6) utilizes the azimuth of the lineation data to investigate the spatial distribution of those two clusters and determine possible locations of the tectonic contact that brings the Eocene metamorphic unit against the Miocene metamorphic unit. 


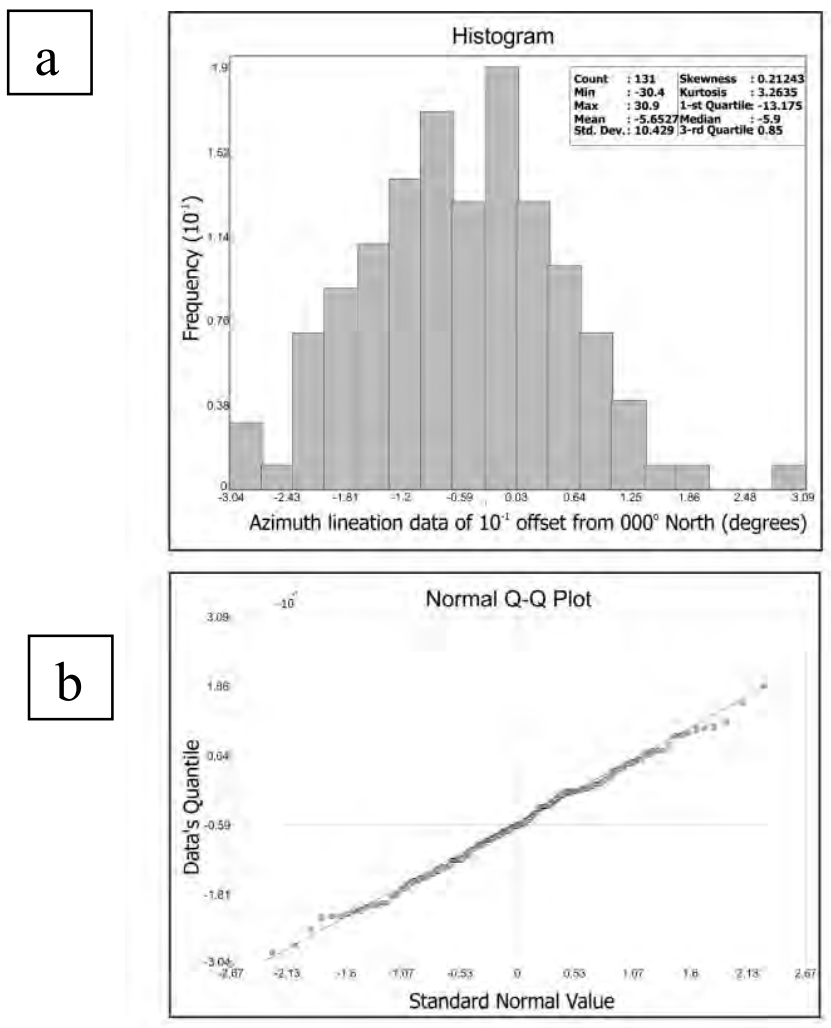

Figure 4 - (a) A histogram that shows the azimuth lineation data from the metamorphic rocks of Santorini. They follow a normal distribution. (b) A Quantile-Quantile (QQ) plot has verified the normality of the data.

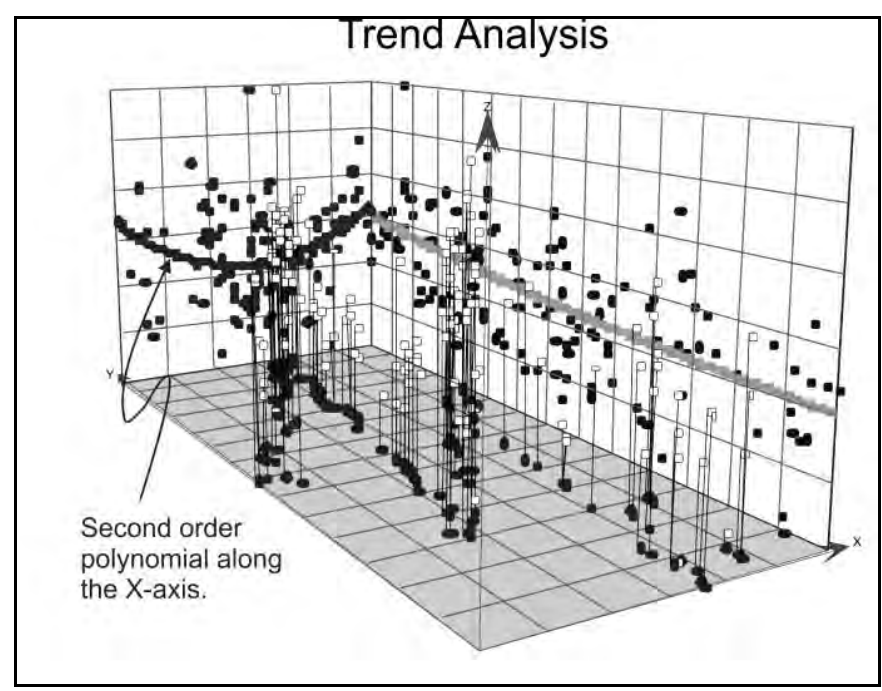

Figure 5 - Trend analysis of the azimuth lineation data along the 3.200 meters outcrop of metamorphic rocks in Athinios. X-axis projected points show the non-random surface component (black points; westward aspect of the slope), while the $\mathrm{Y}$-axis projected points show no significant trend pattern. 


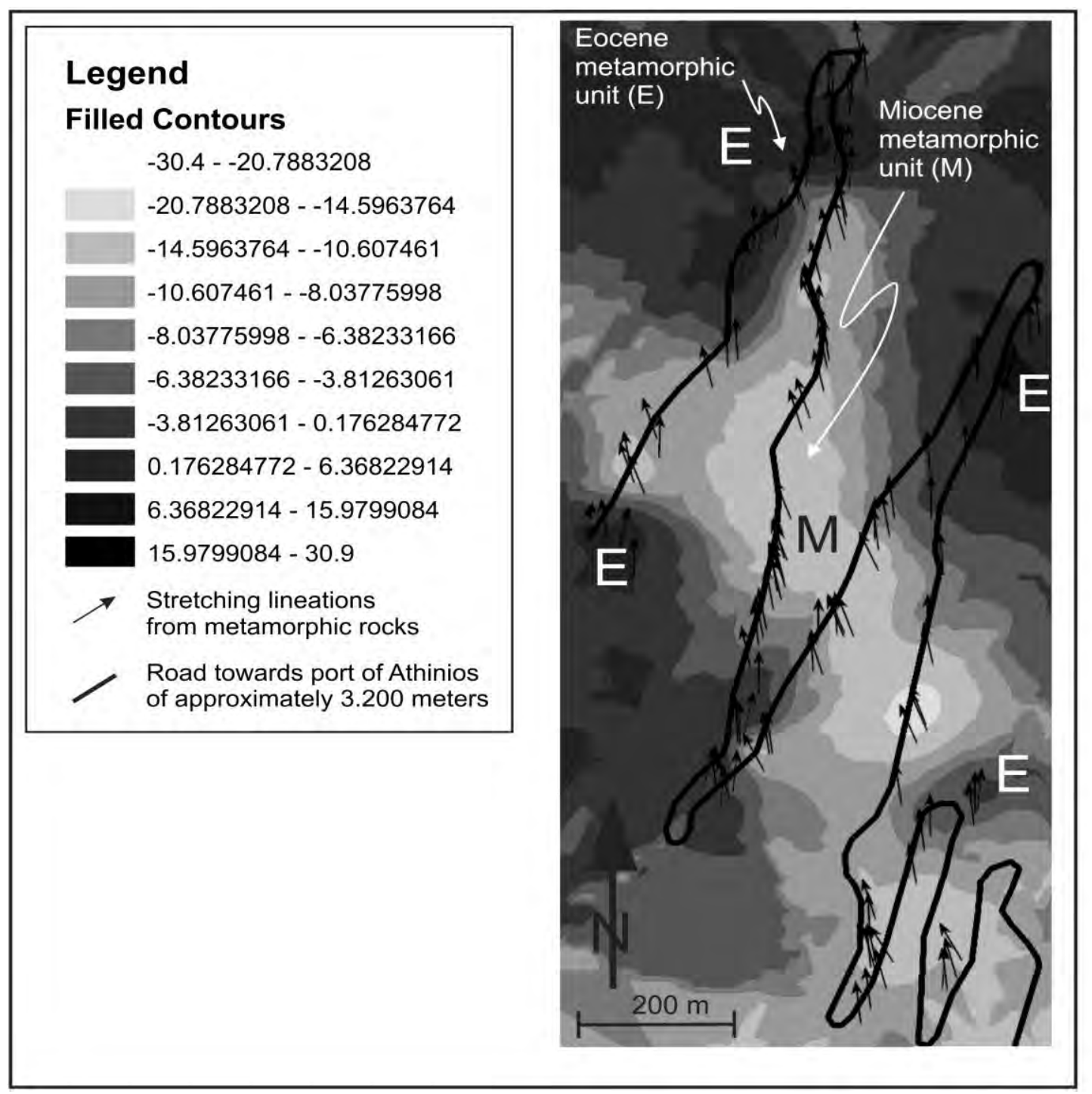

Figure 6 - Prediction map of the azimuth lineation data at the Athinios slope area where the Eocene metamorphic unit (E) rocks are in tectonic contact against the beneath Miocene metamorphic unit (M) of Santorini are exposed along the 3.200 meters outcrop of metamorphic rocks in Athinios. Considering zero as a North reference, data range from $30.4^{\circ}$ degrees (that is 329.6$)$ to $30.9^{\circ}(030.9)$.

Table 1 - Cluster analysis of azimuth lineation data from the metamorphic rocks of Athinios, Santorini.

\begin{tabular}{lccccccc} 
Rock Unit & N & Range & Minimum & Maximum & Mean & Std. Error & Std. Deviation \\
\hline LMU & & & & & & & \\
UMU & 56 & 33.60 & 27.70 & 61.30 & 34.37 & 0.83 & 6.19 \\
& 75 & 26.70 & .00 & 26.70 & 17.57 & 0.73 & 6.34
\end{tabular}




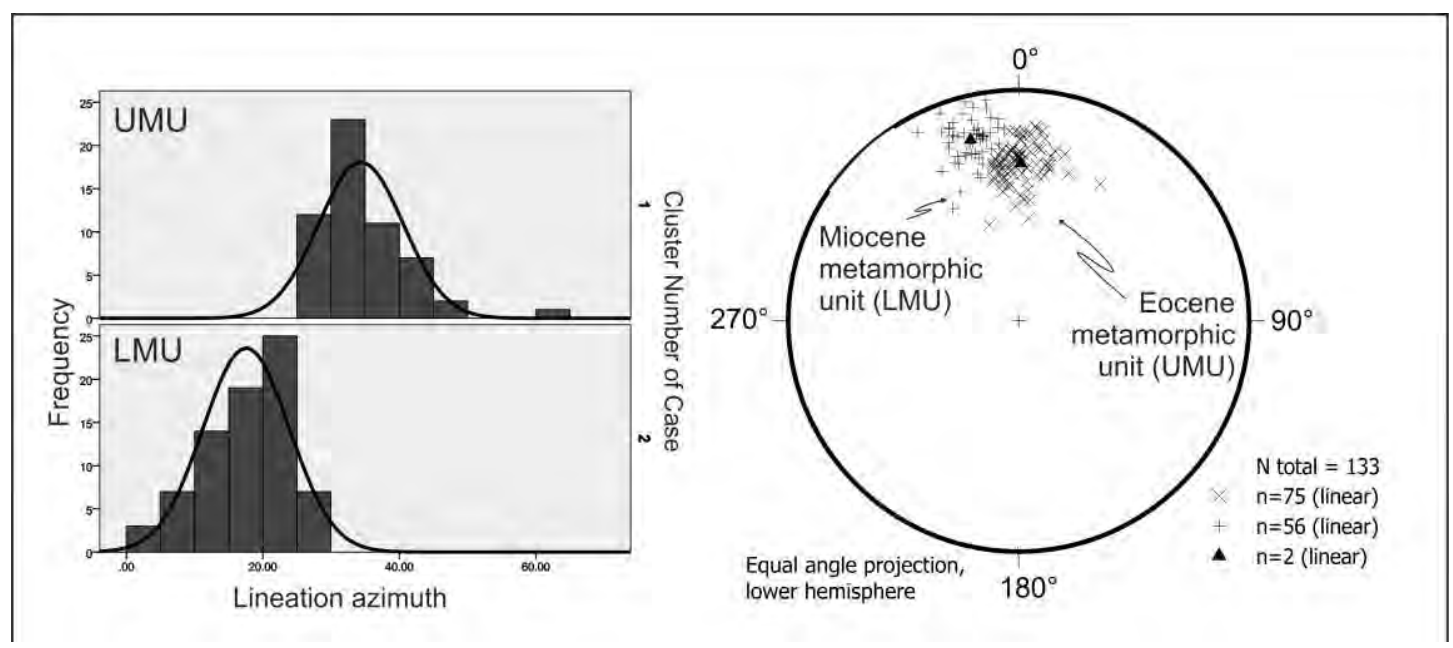

Figure 7 - Two populations of azimuth lineation data derived by cluster analysis from the upper metamorphic unit (UMU) rocks and lower metamorphic unit (LMU) rocks of Athinios, Santorini. Stereonet showing the two clusters projected on an equal angle projection, lower hemisphere.

\section{Results and interpretation}

\subsection{Structural Data Interpolation Map Using GIS}

Lineation directions $(\mathrm{n}=131)$ range from $329.6^{\circ}$ to $030.9^{\circ}$ degrees. Considering zero as a North reference, data range from $-30.4^{\circ}$ (that is 329.6$)$ to $30.9^{\circ}(030.9)$ (Figure 6). This is a range of approximately $60^{\circ}$ degrees, compared to some $90^{\circ}$ degrees of variation shown in the Kythera lineation data (Marsellos \& Kidd, 2008; Marsellos et al., 2010). A lineation histogram (Figure 4) of the Santorini-Athinios azimuth data shows that they follow a normal distribution with a mean value at $354.3^{\circ} \pm 0.9^{\circ}$.

Cluster analysis in this normal distribution has shown two subsequent populations. The first ranges from $329.6^{\circ}$ to $356.3^{\circ}$ with a mean value at $347.2^{\circ} \pm 0.73^{\circ}$ and a standard deviation of $6.2^{\circ}$, and the second ranges from $357.3^{\circ}$ to $030.9^{\circ}$ with a mean value at $003.4^{\circ} \pm 0.83^{\circ}$ and standard deviation of $6.3^{\circ}$. Data were plotted in a stereonet and the two clusters may imply (Figure 7) that there are two metamorphic units with similar approximately N-S direction stretching lineations in contact with each other at the sudden changes of azimuth lineation directions.

All the tectonic contacts between the upper metamorphic cooling unit (Eocene) against the lower metamorphic cooling unit (Miocene) were almost impossible to locate in the field. Construction of a prediction map showing the lineation azimuth distribution of the metamorphic rocks, and the spatial distribution of the two clusters, has facilitated mapping and constraining locations of tectonic contacts. A classification map derived after assigning the two populations of lineation data to the known cooling ages of the Eocene and Miocene metamorphic rock units reveals the possible spatial distribution of those two units (Figure 6).

The results of the predicted locations of contacts were then verified in the field, which facilitated the entire mapping process and further sampling. It allowed us to locate major outcrops that show the occurrences of those two metamorphic units that exhibit two different clusters of stretching lineation populations, and may imply different extensional contexts.

The first population of lineation data shows a range from NNE- to N-trending (Figure 7), while the second population ranges from $\mathrm{NNW}$ - to $\mathrm{N}$-trending lineation. Clustering of those lineations from the two metamorphic rocks may imply two different extensional contexts. The Hellenic arc ex-

$\underline{\text { XLVII, No } 3-1486}$ 
tends along a NW-SE direction from Peloponnese through Kythera and western Crete, and it turns $\mathrm{E}-\mathrm{W}$ in central and eastern Crete. It is reasonable to assume, therefore, that the NNE-trending lineation cluster of the Eocene metamorphic rocks was caused by Eocene arc-normal extension. Whereas, the arc-parallel extension previously documented from Miocene Kythera metamorphic extensional structures is likely equivalent to the NNW-trending lineation cluster from the Miocene Santorini metamorphic rocks. The Santorini Miocene extensional structures that show almost arcparallel extension suggesting that arc-expansion enhanced by intensive arc-parallel extension has took place adjacent to the forearc and toward inner zones such as at the recent volcanic arc and nearby the backarc, as well as the forearc itself.

\section{Conclusion}

A geostatistical map of ordinary Kriging type displays the detailed distribution of two lineation populations corresponding to two distinctive metamorphic units. This methodology allows a quick mapping procedure for revealing tectonic contacts or locations for structural and/or thermochronological sampling, such as the Santorini metamorphic rocks, which show different cooling age and similar stretching lineations.

\section{References}

Aldenderfer M.S. and Blashfield R.K. 1984. Cluster analysis, Published in Beverly Hills, Sage Publications.

Blake M.C. Jr Bonneau M., Geyssant J., Kienast J.R., Lepvrier G., Maluski H. and Papanikolaou D. 1981. A geologic reconnaissance of the cycladic blueschist belt, Greece, Geological Society of America, 92, 247-254.

Brix M.R., Stockhert B., Seidel E., Theye T. Thomson N. and Kuster M. 2002. Thermobarometric data from a fossil zircon partial annealing zone in high pressure-low temperature rocks of eastern and central Crete, Crete, Tectonophysics, 349, 309-326.

Brun J.P. and Faccenna C. 2008. Exhumation of high-pressure rocks driven by slab rollback, Earth and Planetary Science Letters, 272, 1-7.

Doublier M.P. and Hartley G. 2012. Digital technologies and regional field mapping: an overview, Structural Geology and Resources, 70-74.

Druitt T.H. and Francaviglia V. 1992. Caldera formation on Santorini and the physiography of the islands in the late Bronze Age, Bull. Volcanol., 54, 484-493.

Druitt T.H., Edwards L., Mellors R.M., Pyle D.M., Sparks R.S.J., Lanphere M., Davies M. and Barriero B. 1999. The Santorini Volcano, Geological Society Special Memoir, vol. 19, Geological Society Pub House, London, 165 pp.

Everitt B.S. 1993. Cluster analysis, ${ }^{3 r d}$ ed., Published in London, E. Arnold, New York, Halsted Press.

Fassoulas C., Kilias A. and Mountrakis D. 1994. Post-nappe stacking extension and exhumation of the HP/LT rocks in the island of Crete, Greece, Tectonics, 13, 127-138.

Jolivet L., Faccenna C., Goffé B., Burov E. and Agard P. 2003. Subduction tectonics andexhumation of high-pressure metamorphic rocks in the Mediterranean orogens, Am. J. Sci., 303, 353-409.

Kilias A., Mountrakis D., Tranos M. and Pavlides S. The prevolcanic metamorphic rocks of Santorini island: Structural evolution and kinematics during the Tertiary (South Aegean, Greece) - EVOP, 2nd Workshop on European Laboratory Volcanoes, In: Casale R., Fytikas M. et al., 23-36., 1996.

Lister G.S., Forster M.A., and Rawling T.J. 2001. Episodicity during orogenesis, Geological Society, London, Special Publications, 184, 89-113,

Marsellos A.E. and Kidd W.S.F. 2008. Extension and Exhumation of the Hellenic Forearc Ridge in Kythera, J.Geology, vol. 116, 640-651.

XLVII. No $3-1487$ 
Marsellos A.E., Kidd W.S.F. and Garver J.I. 2010. Extension and exhumation of the HP/LT rocks in the Hellenic forearc ridge, American Journal of Science, vol. 310, 1-36.

Marsellos A.E., Foster D. A., Min K., Kamenov G. D., Kidd W.S.F., Garver J. and Kyriakopoulos K. 2012. A structural and thermochronological study of Santorini detachment in Santorini Island, Aegean Sea, American Geophysical Union, December 2012, San Francisco, Abstr. Program. T43E-2722.

McCafrey K.J.W., Jones R.R., Holdsworth R.E., Wilson R.W., Clegg P., Imber, J., Holliman N. and Trinks I. 2005. Unlocking the spatial dimension: digital technologies and future of geoscience fieldwork, J. of Geol. Soc. of London, v. 162, 1-12.

McClusky S., Balassanian S., Barka A., Demir C., Ergintav S., Georgiev I., Gurkan O., Hamburger M., Hurst K., Kahle H., Kastens K., Kekelidze G., King R., Kotzev V., Lenk O., Mahmoud S., Mishin A., Nadariya M., Ouzounis A., Paradissis D., Peter Y., Prilepin M., Reilinger R., Sanli I., Seeger H., Tealeb A., Toksoz M.N. and Veis. G. 2000. Global Positioning System constraints on plate kinematics and dynamics in the eastern Mediterranean and Caucasus, Journal of Geophysical Research, Vol. 105, No. B3, 5695-5719.

Mountrakis D., Pavlides S., Chatzipetros A., Meletlidis M., Tranos G., Vougoukalakis G. and Kilias A. Active deformation of Santorini, EVOP, ${ }^{2 n d}$ Workshop on European Laboratory Volcanoes, In: Casale R., Fytikas M. et al., 13-22., 1996.

Papastamatiou L. 1956. Sur l'ege des calcaires cristallins de l' ile de Thera (Santorin), Bull. Geol. Soc. Greece, 3, 1, 104-113.

Pavlis T., Hurdado J.M., Langford R.P. and Serpa L.F. 2012. Field geology in the $21^{\text {st }}$ century: not what you learned in school, Structural Geology and Resources, 141-143.

Ring U., Glodny J., Will T. and Thomson S. 2010. The Hellenic Subduction System: HighPressure metamorphism, exhumation, normal faulting, and large-scale extension. Reviews in advance, Annu. Rev. Earth Planet. Sci., 38, 45-76.

Skarpelis N. and Liati A. 1987. Granite intrusion, skarn formation and mineralization in the metamorphic basement of Thera, Cyclades, Greece, ${ }^{\text {sth }}$ Meeting European Geological Societies, Dubrovnik, Abstr., p. 81.

Skarpelis N. and Liati A. 1990. The prevolcanic basement of Thera at Athinios: Metamorphism, Plutonism and Mineralization, Proc. of the Third International Congress "Thera and the Aegean World III", Hardy D.A. ed., The Thera Foundation, London, 2, 172- 182.

Skarpelis N., Kyriakopoulos K. and Villa I. 1992. Occurrence and ${ }^{40} \mathrm{Ar} /{ }^{39} \mathrm{Ar}$ dating of a granite in Thera (Santorini, Greece), Geologische Rundschau 1992, Volume 81, Issue 3, 729-735.

Skourtsos E. and Lekkas S. 2010. Extensional tectonics in Mt Parnon (Peloponnesus, Greece), Int. J. Earth Sci. (Geol. Rundsch.), Volume 100, Issue 7, 1551-1567.

Tataris A. 1964. The Eocene in the semi-metamorphosed basement of Thera island, Bull. Geol. Soc. Greece, 6, 232- 238 (in Greek with English summary).

Thomson S.N., Stockhert B. and Brix M.R. 1998. Thermochronology of the high-pressure metamorphic rocks of Crete, Greece: implications for the speed of tectonic processes, Geology, 26, Vol. 259-262.

Thomson S.N., Stockhert B. and Brix M.R. 1999. Miocene high-pressure metamorphic rocks of Crete: rapid exhumation by buoyant escape, In Ring, U., Brandon, M., Lister, G.S., Willet, S. (editors), Exhumation Processes: Normal Faulting, Ductile Flow and Erosion. Journal of Geological Society of London, Special Publication, Vol. 154, 87-107.

Whitmeyer S.J., Nicoletti J. and De Paor D.G. 2010. The digital revolution in geologic mapping, GSA Today, 4-10. 